\title{
BOARD-LEVEL RECRUITMENT ERRORS. AREAS OF MOST COMMON OCCURRENCE AND PREVENTION METHODS
}

\author{
Maciej Mikucki*, Dorota Wiśniewska-Juszczak**, Magdalena \\ Jabłońska***
}

\begin{abstract}
Background. Finding a suitable candidate for a senior-level position is a complex task and its results are likely to have a significant effect on short- and long-term functioning of the company. Hence, it is especially important that the recruitment process is conducted in a structured and reliable manner. Unfortunately, research in the area of candidate selection shows that many a time it is not the case.
\end{abstract}

Research aims. The aim of the paper is to provide a concise overview of most common cognitive errors and organisational mistakes typical for the recruitment process as well as some recommendations to tackle these challenges.

Methodology. A review of literature in the field of management studies was conducted in order to determine the most common flaws in the selection of candidates for senior-level positions. The results of literature search were enriched with examples and observations from the authors' professional experience and interpreted with reference to research in cognitive and social psychology.

Key findings. Organisational mistakes such as no recruitment plan, no clear description of a desired candidate profile, failing to use effective recruitment methods other than the interview, lack of cultural fit and no understanding of the market as well as inadequate communication with candidates and cognitive biases in the decision-making process were identified as the most common flaws of the recruitment process. Recommendations on tackling these issues were provided.

Keywords: recruitment process, candidate selection, senior-level position, cognitive bias.

* Szkoła Główna Handlowa w Warszawie. E-mail: mmikucki@op.pl

** SWPS Uniwersytet Humanistyczno-Społeczny.

E-mail: Dorota.Wisniewska-Juszczak@swps.edu.pl

*** SWPS Uniwersytet Humanistyczno-Społeczny. E-mail: mjablonska2@swps.edu.pl 


\section{INTRODUCTION}

External search for top executives, especially board members and directors, reporting directly to the presidents of the board, is a delicate, lengthy, and confidential process. It requires time and effort (Russo, Rietveld, Nijkamp \& Gorter, 2000) and has a significant impact on both the daily operations and long-term health of the company. It is also a dominant way for talent acquisition (Cappelli \& Keller, 2014), a process which in the current economic and demographic reality encounters many challenges (Faulconbridge, Beaverstock, Hall \& Hewitson, 2009) as more and more often talented and experienced employees are regarded as a scarce resource that many companies compete for (HRMI Digest, 2007).

The literature in the field of the recruitment process has grown extensively over the last years and increased attention is given to the importance of a properly conducted recruitment (Rynes, Bretz \& Gerhart, 1991). However, a quick revision of research endeavours shows that there seems to be "a mix of optimism and pessimism" (Breaugh $\&$ Starke, 2000) in the field and there still remain many areas that need further exploration and some methodological issues that need to be addressed (Barber, 1998). Furthermore, having accumulated many years of experience in the area of candidate selection, we believe that despite ample scientific evidence for the importance of the process and declared effort on the side of those who conduct it, the daily reality seems to be different as frequently not enough attention and thought is given to the search for a new employee. For instance, very often those responsible for the selection of candidates for top executive positions pay insufficient attention to the process, believing that hiring a reputable headhunter is adequate enough. However, since "recruitment encompasses all organizational practices and decisions that affect either the number or types of individuals who are willing to apply for or to accept a given vacancy" (Rynes, 1991), there is a need to reconsider such an approach.

Given extensive review of the literature on the recruitment process (Barber, 1998; Breaugh \& Starke, 2000; Newell, 2005), it is not our goal to provide a systematic review of all articles published in the field. Instead we would like to concentrate on the presentation and discussion of the most common mistakes that are made by various 
individuals involved in the process. Observing numerous recruitment projects, both from the recruiter and recruited standpoint, we decided to list the most prevailing errors and give our suggestions concerning their minimisation. Our observations are enriched by a thorough review of literature in the field of management studies and cognitive and social psychology that give a theoretical analysis and explanation of the errors. The main aim of the article is to provide both practitioners and researchers, dealing with candidate selection, with a concise overview on recurring cognitive biases and organisational mistakes in the preparation and carrying out of the recruitment process. Although in our work we have concentrated on the obstacles hindering the hiring of best candidates for senior-level positions, our recommendations may be applied to less senior candidate selection processes as well.

There is a number of possible approaches for structuring a review. As we have already mentioned, it is not our purpose to present a systematic review of the recruitment literature and for all those interested in the detailed account on the field we recommend excellent reviews by Barber (1998), Breaugh and Starke (2000), and more recently a meta-analysis by Uggerslev, Fassina, and Kraichy (2012) as well as others cited herein. In the following paper, we will present only a brief overview of the area prior to a more thorough discussion of recruitment errors which are the subject of the study. Our objective is to highlight the most common mistakes in the recruitment process as well as provide recommendations on how to rectify them. Secondly, we want to stimulate the research in the field by providing suggestions for further investigations.

The structure of the paper will be as follows: we begin with a brief discussion of the importance of the top executives' recruitment process, highlighting possible consequences of a choice of a wrong candidate. Then, we briefly define the recruitment process and propose its division into individual steps, analysing one of them in more detail. Having discussed the most common errors at the stage of searching for and selecting the right candidate, we propose effective methods to minimise risk by suggesting specific actions that should be taken. We finish with recommendations regarding the areas worth further scientific interest. 


\section{The consequences of recruitment errors}

Individuals holding senior management positions have full powers to act on behalf of the owners of the company. Representing the interests of shareholders, they have access to detailed knowledge about the company and authority to make decisions concerning the direction of its development (Van Clieaf, 1992). Their responsibilities pertain not only to the allocation of significant funds, but also taking personal decisions concerning the shape of the organisation. Leaders of the company are not subject to a meticulous and daily control but are rather accountable for medium- or long-term results of their actions. Executives can expose a company to significant losses, not only by taking wrong decisions but also by failing to take any actions. Such lack of decisiveness and other skills in turn lead to the decision-making paralysis, the result of which may significantly influence the company's competitive position.

It is estimated that the cost of an unsuccessful recruitment ranges from 35 to $100 \%$ of the annual employee cost (Deems, 1995). Yet the cost is even greater, since an incompetent leader causes valuable employees to leave and exposes the company to a loss of reputation among other team members. Additional aspects worth mentioning are a crisis of trust within the management team, questioning the leadership due to the lack of corrective actions from either the board or CEO and the distraction from the main goal of the enterprise a profitable growth (Lachowski, 2013).

\section{Stages of the recruitment process}

Finding the right candidate for a senior-level position is a difficult and multi-stage process. Although there might be pressure to advance the search and fill in the post with a "good enough" applicant as soon as possible, the key success factor and the most important element of a successful recruitment is to understand that this process encompasses many steps and cannot be narrowed down to several conversations conducted with a prospective employee.

Literature in the field of personnel selection offers a number of definitions to describe recruitment. For instance, Barber (1998) states that "recruitment includes those practices and activities carried on by 
the organization with the primary purpose of identifying and attracting potential employees" (p. 5). In their work, Taylor and Collins (2000) extend this definition, saying: "Recruitment includes the set of activities undertaken by the organization for the primary purpose of identifying a desirable group of applicants, attracting them into its employee ranks, and retaining them at least for the short term" (p. 306).

For the most part, each definition characterises recruitment as a complex and multi-stage process. Most typically one can distinguish its four main steps: identification of vacancy and need definition, a job analysis, the production of a job description and a person specification (Carroll, Marchington, Earnshaw \& Taylor, 1999). Further steps include the search for the most suitable candidate and their "fit" analysis, as well as negotiation and signing of the employment contract. Finally, a new employee is introduced to the company and accepted by the team. The following article will focus on cognitive biases and other recruitment errors that emerge during the stage of searching and selecting the most suitable candidate.

\section{RECRUITMENT ERRORS}

Below we list and discuss the most common recruitment errors. Their sequence corresponds more to the stage of the search process during which they may appear rather than to their frequency or importance.

\section{Mental deceptions}

Despite best intentions, extensive training and good will, a recruitment process is not conducted in a purely rational manner. Those responsible for the recruitment and all participants of the process are subject to emotions and are prone to cognitive biases they even do not realise (Kataoka, Latham \& Whyte, 1997). Such errors are not restricted to the selection of best candidates only, but are characteristic of all types of decision-making processes as they represent a heuristic functioning of the human mind (Kahneman, 2013). From the perspective of the recruitment process, these errors can contribute to the selection of a candidate based on irrelevant information or irrational premises. Below we briefly describe these aspects of unconscious errors of reasoning that according to Daniel Kahneman (2013), a renowned 
psychologist and the Nobel-prize winner, seem to be most common obstacles in making a rational decision.

1) During both the recruitment and decision-making process one can be prone to the availability bias. This error arises when a person attaches a greater importance to events which are easily recalled from memory and carry stronger emotional load. Doing that one is likely to overrate the probability of an unlikely event or its significance. In the recruitment process, a recruiter can display this form of a bias if they let one piece of information (usually recent, emotionally laden or distinct from others) cloud their judgment.

2) Evaluating a candidate's competence and suitability based on a well-known and reputable university they graduated from or a prestigious company they worked for leads to the representativeness bias. It is the phenomenon in which a positive opinion about a university or another company is carried over to the candidate, although a direct relationship is not guaranteed.

3) Recruiters tend to also often fall for the so-called a n c hor ing bia s in which they "anchor" their judgments to a particular piece of information which becomes a reference point against which all new facts and opinions are compared. For example, a recruiter may place great importance on the number of years in a similar position specified in the candidate profile description, ignoring such information as the type or size of the organisation an applicant worked for and their other experience.

4) The recruiters are also likely to fall for the confirmation bias if they put too much attention to their first impression about an applicant. In such a situation, they are likely to accept new pieces of information only if they confirm what the recruiter already thinks about the candidate. For instance, the prospective employee is evaluated very positively based on great references from their previous employer, even though they do not fully meet the expectations of the candidate profile and they underperformed during the interview. The recruiter, however, fails to notice that their opinion is based on earlier pieces of information, e.g. the fact that other trustworthy sources had given the applicant a good opinion that the recruiter believed in since the beginning. 
Apart from biases studied by Kahneman (2003), psychologists have identified numerous other effects that can hinder a rational decision-making process aiming at the selection of the best candidate for the post (Szkop, 2012).

One of the most frequent errors of the human mind is the so-called halo effect which constitutes a specific type of the confirmation bias. A recruiter prone to this bias forms their overall impressions about the applicant based on one (generally positive) outstanding feature that outshines all other characteristics of a prospective employee. As a result, the total and unbiased assessment of the candidate is impossible or distorted. The negative counterpart of the halo effect is the so called horns effect in which one unfavourable trait of the potential employee looms over all other generally positive information about them so much that it prevents the recruiter from even considering potential undiscovered strengths of the candidate.

An objective recruiter should also beware of the similarity effect that may result in more favourable assessment of an applicant that resembles in some way the recruiter as well as the contrast bias when the recruitment specialist evaluates (more or less favourably) the candidate based on the performance of other applicants or themselves. Although the comparison of a prospective employee against other contenders is a standard procedure of the recruitment process, it may result in biased judgments when more than one recruiter is involved in the process or if the candidate against which all other applicants are compared can be perceived as an outlier.

Stereotypes are yet another obstacle to rational decision-making. Research shows that they are as serious as underestimated and despite training they are likely to influence biased decisions of choosing males over females for leadership positions (Kawakami, Dovidio \& van Kamp, 2005). The disproportions in male to female presence at the board-level positions can be further explained by the similarity effect which causes boards to be homogenous (Jackson et al., 1991), thus losing access to new ideas and not allowing to challenge the status quo (see Spence, 2016).

\section{No clear description of a desired candidate profile}

The job description preceded by a thorough analysis (Russo, Rietveld, Nijkamp \& Gorter, 1995) is the first and necessary step leading to the successful recruitment. Some sources list it as a crucial and the most 
important factor of success (Szkop, 2012), which, unfortunately, is not always sufficiently considered (Vieira Campos Proença \& Valente Dias de Oliveira, 2009). Following oversights regarding a candidate profile have been identified:

1) Competencies and desired experience, both quality- and depthwise, are not clearly defined.

2) Requirements regarding cooperation with others (especially peers) are not well-defined.

3) The aspect of a candidate's personality fit to the team is not given enough consideration.

4) Perfect candidate description is assigned to the head-hunting company who does not know its client well enough which may lead to template solutions.

Research shows that these mistakes are replicated on a massive scale as only $52 \%$ of companies have competence profiles and even a lower number of them (40\%) use personal audits (Wachowiak, 2006). From our observations, we conclude that it is vitally important to establish a deep understanding of skills and competencies required for the position as these will in turn define the search. Another common misconception is a belief that the best candidates can be found at the competition. However, it may happen so that the company searching for a candidate is by far the best on the market and no competitor, nor their executives, can measure up. In such a case hiring someone from the competition will most likely be detrimental to the company (Van Clieaf, 1992).

\section{Misunderstood recruitment objective}

It is often assumed that the purpose of the recruitment process is to select the best candidate from those applicants whose names have been put on the shortlist proposed by the executive search company (Kostera, 2000). However, it seems to be more reasonable to hire only such a candidate who is suitable for the position. The search process should last until the right person meeting all job requirements is found. A compromise in this area is potentially dangerous for the company's long-term success and survival. It must be borne in mind, however, that this assumption holds only if the expectations towards candidates are realistic. 


\section{No recruitment plan}

A well-planned recruitment process should be the basis for action (Roselius \& Kleiner, 2000). In order to properly manage the recruitment process rather than let it take its own course, the following questions need to be addressed:

1) How many stages will there be and how will they be organised?

2) Will there be a psychological tests used?

3) Will the Assessment Centre be adopted?

4) Will there be a decision-making matrix/candidate scoring system used for the evaluation and selection?

5) Who are the stakeholders of the project, i.e. the owner of the project, advisory persons/bodies, service providers?

The fight for talent is intense in today's economic environment (Faulconbridge et al., 2009) and a good recruitment process becomes necessary to provide the company with an appropriate quality of the personnel. Companies compete with each other also in the field of creating innovative recruitment programs and only a thoughtful approach will provide the highest quality candidates (HRMI Digest, 2007).

\section{Careless selection of a head-hunting company and lack of proactive cooperation}

For some time now there has been a consensus that a search for executive positions requires a headhunter as an intermediary between the company and a potential employee (Bull, Ornati \& Tedeschi, 1987). Since the recruitment for top positions is a relatively narrow field of practical knowledge, there are not many companies on the market with sufficient expertise to conduct such a process effectively (Clark, 1992). Such a restricted choice should make the selection of the head-hunting agency easier, however the recruitment success will largely depend on the personal professionalism and skills of the consultant who runs the project (Mileham, 2000). A careless choice of a head-hunting company or a particular consultant may be very expensive for the organisation if it results in the employment of an unsuitable candidate. It also should be borne in mind that the consultant cannot be leading the process - this is the role of the "process owner" on the company's side. 
This last comment is vitally important as it is the company - and not the head-hunter - who should define the qualities of the candidates. If the recruiter and the company have a different understanding of what "talent" is and what candidate the company is looking for, the list of proposed contenders delivered by the recruiter will not answer the employer's needs. Furthermore, it has been observed that such misunderstandings have a considerable effect on the recruitment process (Faulconbridge et al., 2009).

\section{Too many people with a decision right}

There is much of scientific evidence suggesting that group decision-making may lead to major cognitive errors (Kerr \& Tindale, 2004) that may affect the recruitment process. However, even if the group defies such biases, it is still better if the final decision about the employment of a candidate is reached by one person who would bear full responsibility for the choice. The recruitment for top positions involves many senior executives in the process and most often each of them has a different opinion, a situation which may lead to conflicting demands on candidates and the process itself. Teams made of senior-level executives may have a tendency to polarize their viewpoints and that may lead to the radicalisation of the expectations towards the candidate (Rousseau, Aubé \& Savoie, 2006). Psychological studies on group processes have shown that the position of the group is more extreme because the views of individual members become more extreme after the discussion and under the influence of the need to compete as well as the process of social comparison (Moscovici \& Zavalloni, 1969).

\section{Selecting a candidate good for now and not for the future}

Companies conducting a senior position search often realise that in a year or two they will have to perform a major adjustment of the strategic direction or its business model. If an expansion and increase of the company's size are planned parallel to the recruitment process or in the near future, it is likely that the requirements towards the candidate will change significantly (Ansoff, 1965; Coad, 2007; Van Clieaf, 1992). Unfortunately, research shows that when searching for new employees, the companies look for candidates that answer their current (and not future) requirements, culture, and business 
size (Russo, Gorter, Nijkamp \& Rietveld, 1997). As a result, a great accountant for the position of the financial director is acquired, although the company will in the near future need a strategist with extensive analytical and adaptation skills.

\section{Lack of cultural fit and no understanding of the market}

Each company has its own culture (Smircich, 1983). In some companies, the culture is described and clearly communicated in the form of the set of values, mission, and vision facilitating the explanation of the internal rules to people outside the company (Birkinshaw, Bresman \& Hakanson, 2000). However, a well-thought and planned use of knowledge about the prevailing culture during recruitment is rare and thus companies often face challenges pertaining to cultural fit between the organisation and a new employee. A good example here may be a compromise-driven organisation that has hired a top-level executive who operates aggressively or a company with a very strong hierarchy culture that rejects those who display a democratic management style.

Power distance and the division into collectivism vs. individualism is another important aspect worth looking at, especially if a potential new manager and their future subordinates come from different countries or cultures (Hofstede, 2007; Mazur, 2012). Power distance reflects the culture's dominant approach to inequality, expressed in the relation of the subordinates to superiors (Mazur, 2012). In cultures, which treat inequality as a natural feature or even worthy of respect, the power distance is significant. In cultures treating inequality as unavoidable, the power distance is much smaller. It is easy to imagine negative consequences of such a misfit for a team, however, also a new manager - used to democratic style, open to criticism and interested in opinions of their subordinates - may find themselves in a difficult position if they are employed in an organisation at which power distance is very high (Hofstede, 2007).

In the case of international recruitment processes, it is essential that all their stakeholders are aware of their cultural differences and challenges that such a recruitment may bring (Ma \& Allen, 2009). It is also recommended that the recruiters make sure that the candidate that they are looking for matches well the requirements of the market that he or she is going to operate in. 


\section{Inadequate communication with candidates}

Candidates are rarely treated as partners and they are not provided with sufficient information concerning the recruitment process and its stages. A prolonged time of replying to messages, lack of information about people the candidates are going to meet as well as insufficient information about the company, its operation style, and culture, seem to be most common communication errors which may result in the withdrawal of valuable candidates. The recruiters should be aware of the fact that the evaluation process is bilateral, i.e. although it is often believed that it is the applicant that is under scrutiny, the candidates also make judgments and evaluations of recruiters and the company that they may work for (Russo et al., 1995). Another common mistake committed by recruiters is not thanking rejected candidates for the participation in the process (Szkop, 2012). Equally often, in more than $45 \%$ of the cases, recruiters do not provide any feedback to the candidate (Molenda, 2010). Such practices must be avoided since they have a long-term effect on the perception of the company and its goodwill.

\section{Lengthy recruitment process}

A sluggish recruitment process may lead to negative consequences for the company twofold. Firstly, the selection of candidates for managerial positions can last several months, during which time a candidate is quite often left to themselves, while the company is coordinating meetings between the recruiters and other applicants. Frequently, the company does not communicate with candidates sufficiently and effectively, leaving them "in the dark." Such practices may result in applicants feeling disappointed and discouraged by the prolonged process which in turn often results in their withdrawal from the application (Arvey, Gordon, Massengill \& Mussio, 1975). Secondly, as companies undergo internal restructuring or carry out mergers and acquisitions (DePamphilis, 2013), it may turn out that a candidate selected by previous decision-makers does not meet the requirements of their successor. Based on our experience we can report that changes in the company frequently lead to a situation when the candidate's profile no longer matches the position's requirements. 


\section{Reluctance to use recruitment tools}

Few companies use tests and those that do usually focus on the personality ones, often in their simplified, free versions. Companies employing more tools for the same process tend to be interested in the motives of candidates (Russo et al., 2000). Testing candidates in terms of their knowledge, experience and skills remains uncommon not only in the case of the highest positions (Jaworowska, 2011). A similar approach is usually taken towards the Assessment Centre, even though the method has been recognised as the most effective tool for assessing the candidate's competence (Ballantyne \& Povah, 2004). Other tools with proven effectiveness include ability tests, assessment of biographical data, or personality tests (Witkowski, 2007).

\section{Lack of preparation for an interview}

The conversational interview is the most widely practiced recruitment tool used in over $85 \%$ of top executives staffing processes (Szkop, 2012). Many a time, however, it is the only method employed. This over-reliance should encourage recruiters to take a very careful and rational approach towards such conversations. In many cases though, conversations do not have a proper structure that would allow uncovering specific actions and candidates' modus operandi in their earlier professional career. Prior experience remains to be the best predictor of candidates' future behaviour and actions (Deems, 1995). The conversation based on "intuition" of a person conducting the interview will probably lead to the selection of a person similar to the recruiter rather than the candidate with the highest potential (Roselius \& Kleiner, 2000). Candidates are perfectly aware of this phenomenon and carefully use it (Raffler-Engel, 1983). Although such a practice is universal, it is fundamentally incorrect to interview different candidates using different questions, leaving the recruiter with no comparison between the contenders. A casual and unstructured conversation, the recruiter taking no notes and the lack of agreed methodology on how the responses should be assessed endanger the process even further. 


\section{Failing to verify sources}

Lack of CV verification and no background check of references seem to be a common practice among the recruiters. According to available data, 30 to $60 \%$ of candidates, including those for senior-level positions, do not tell the truth in their CVs (Szkop, 2012). No CV verification, even in the form of an in-depth discussion of biographical details, seems risky. A thorough verification of information about the candidates for higher positions seems vital as it may reveal that candidates have neither the education nor senior expertise they claimed.

Failing to verify references is another obstacle to effective recruitment. Only $30 \%$ of companies analyse and check references provided by candidates (Wachowiak, 2009) and even fewer contact previous companies without the candidate's knowledge. Employers' reluctance to share any information apart from the employment date and names of the positions held hinders the process even further (Bell, 1992). However, a growing practice of informal social contacts between recruiters (social media, the Internet, etc.) may have a positive impact on the change in this respect (Gërxhani \& Koster, 2015).

\section{RECOMMENDATIONS}

Having discussed the most common errors hindering the selection process, we would like to propose some actions that can minimise the risk of recruiting an unsuitable candidate.

\section{Structured interviews}

One of the best defences against cognitive biases and decision-making errors is being aware of them and remaining watchful at every stage of the recruitment process (Hogarth, 1980). Although heuristic reasoning is inscribed in the human nature, repeated practice, careful examination of facts, not rushing into conclusions, and persistent challenging of one's previous assumptions should help the recruiters in making rational and informed decisions.

Using a structured interview is another effective way to keep the selection process reliable (McDaniel, Whetzel, Schmidt \& Maurer, 1994). 
Structured interviews are a rigorous method in which all candidates are asked the same questions, preferably in the same order, and are compared against similar standards. The method is recommended especially if there are more recruiters involved in the process or one interviewer will conduct interviews over an extended period of time. A more lenient alternative to structured interviews are semi-structured interviews that allow new topics to be brought up during the conversation (Graves \& Karren, 1996). The method is also frequently used during the recruitment process as it gives the recruiter a chance to inquire further about situations from the candidate's life, allowing for better understanding of their way of operating and management styles.

Although each interviewer should be given some liberty, a relatively detailed framework of topics to be covered during the talk should be prepared and followed. Furthermore, as human memory is fallible, it is essential that the recruiters take detailed notes from their meetings with the candidates which can be later set against the impressions they gathered during the interview. Finally, the use of standardised scoring guides may further enhance objectivity and reliability of the assessment process (Kataoka, Latham \& Whyte, 1997).

\section{Recruitment assessments and its plan}

Before the process is started, still at the internal stage, one person needs to be selected to have the right to decide. Defining those who can have the right to veto, like a regional head or the company owner, is the next step. Finally, other team members whose opinion will be taken into consideration need to be nominated. All these choices should be clearly communicated to the participants of the recruitment process.

A profile of the candidate for the head-hunting company needs to be prepared. This should be done based on the expectations concerning the duties of an employee and considering the developmental aspects of the company. One cannot forget about checking with clients, both internal and external, what they expect from this position (Van Clieaf, 1992). The verification of the needs should be the responsibility of the decision maker and it cannot be done by a simple process of matching the job description with the company's preferred behaviour statements. This part of the search process will decide about its later course, costs, and final result. Imprecisely described requirements 
will be the basis for misunderstandings and possible disagreements between the company, headhunting agency, candidates as well as all other participants of the recruitment process.

The profile of the position for candidates should be developed in close cooperation with the headhunting company. This document is to serve the applicants and should not be the same as the candidate's profile. The position profile prepared for candidates should include information on key competences, responsibilities as well as descriptions of expected behaviour (e.g. delegating tasks).

Then, the process needs to be agreed with the advisor: meeting venues, frequency of contact, materials for candidates, etc. A well-prepared recruitment process not only facilitates the decision-making process but can also constitute an important documentation in the case of a dispute concerning the final choice of the candidate. Such conflicts often end with a lawsuit over discrimination and are very costly for the company (Hayes, 1993).

\section{Tools}

Research shows that techniques other than interviews are used too seldom and even this one takes place only in $46 \%$ of cases (Wachowiak, 2009) and that has been confirmed in our research. Apart from the interviews, other available methods include personality tests, graphology, aptitude tests, biographical data and Assessment Centre (Olszak, 2014). Below we have listed the methods that in our opinion are especially worth using.

1) Tests have versatile use (Tixier, 1996) and can be adopted not only to measure personality, but also many work-related areas such as management styles, risk preferences or integrity. The so-called aptitude tests allow to evaluate such skills as numerical and mechanical reasoning or verbal, spatial, and analytic abilities based on the degree, accuracy and speed in which the candidate processes information and answers questions. One has to be however cautious as only proven and recognised tests should be administered, preferably those known to and frequently used by the recruitment company so that there is a basis for comparison. Logical or numerical tests are not recommended for senior executives and their use should be restricted to less senior positions. Verbal reasoning tests are 
highly recommended by all practitioners interviewed by us. Tests are vital as they provide knowledge about a potential employee which allows for taking action prior to the employment. More specifically, it is relatively easier to tackle minor experience or knowledge deficits than to change the candidate's attitude to work (Russo et al., 1995).

2) Case study is yet another effective way to verify the applicant's suitability. The method adopts many forms, but most typically, a potential employee is invited for a 3-4-hour long meeting and asked to solve a specific problem related to, for example, people management. Although this is a time-consuming tool, it gives a chance to assess the way candidates work under time pressure and to compare different proposed solutions. The method also enables an easier and more reliable selection of the person whose style of work is closer to the one typical for the company.

3) Assessment Centre (AC) is regarded as the most effective recruitment method (Witkowski, 2007). Apart from its effectiveness, ACs are quite versatile and come in different forms (Szkop, 2012). A simulation of a professional situation such as a difficult conversation with an employee, motivating a team to work or preparing a development strategy is a great method to gather plenty of information on the candidate. The assessment is done by external consultants based on selected competencies and their behavioural indicators. This method works perfectly well when the new person needs to be well-adjusted to the position requirements, especially in the case of higher managerial staff. It also enables the assessment and comparison of many applicants in a short time. Although this method is expensive, the risk of employing a wrong candidate and costs associated with it seem to be a sufficient reason to use the AC (Szkop, 2012). The results of longitudinal studies and a meta-analysis on the effectiveness of $\mathrm{AC}$ show that the evaluations of candidates during the Assessment Center are a good predictor of the candidate's success or failure in the new job.

Other recruitment tools such as graphology, astrology, biorhythm analysis, or polygraph tests are controversial and their usefulness is questioned (Szkop, 2012). The use of NLP (Neuro Linguistic Programming) 
techniques suggested by some (Olszak, 2014) raises some ethical doubts and we advise extreme caution before deciding to use them.

\section{Communication}

Conducting a recruitment, one should not neglect the wellbeing of all applicants taking part in it and their right to information about the process. Good communication with the candidates not only establishes good rapport but also transmits an image of the company as a professional and respectful employer. Below we provide some suggestions concerning proper communication with the candidates.

1) Information regarding those recruiters that the applicants will meet in the company is a necessary sign of good practice. A brief biographical note about the recruiters will make a professional impression on the candidates.

2) It is worth keeping regular contact with prospective candidates. This is the role of a headhunting company but it is good to ensure such actions happen. Taking into consideration keeping up a good image of the company, it is essential to inform candidates about the rejection of their application (Armstrong \& Taylor, 2014).

3) Candidates' questions are a sign of their interest, but recruiters are also obliged to talk about the company and themselves. Each recruiter should present their opinion of the company to the candidate. The more independent the viewpoint, the easier it is for the candidate to establish their opinion about the environment in which they will work.

4) An information pack about the company makes a good impression on candidates. The set should include information available publicly, but prepared for the recruitment purposes. Such a material should be general, so that it can be used in other recruitments processes (updated if necessary).

\section{CONCLUSIONS}

The aim of the article was to present the most common errors present in the recruitment process and a practical advice on how to avoid them. As we have repeatedly demonstrated, the selection of the most suitable 
candidate for a board-level position is a considerable and complex process, the result of which may have a significant effect on the longterm functioning of the company. Although the organisation may feel pressure to expedite the process, it is essential to remember that the costs of hiring a wrong candidate due to time restrictions are likely to outweigh any potential gains of such a decision. Furthermore, looking for a future employee, the company should keep in mind its strategy and long-term goals, so that a newly hired person can answer the present and, what is even more important, future needs of the company.

After the literature overview, we assess that there are many publications on the recruitment process that can facilitate its preparation and proper carrying out. Based on our experiences and interviews with people involved in the process we have noticed, however, that practitioners show reluctance to carry out the recruitment in an organised and rational manner, failing to adopt structured interviews or communicate adequately with the candidates. Secondly, we have gathered that there is still no broad acceptance for the use of many tools, the effectiveness of which research has repeatedly demonstrated (e.g. Assessment Centre). We hope that the recommendations that we have provided as well as a brief presentation of the most reliable and effective tools that can be used will inspire specialists conducting and managing the selection of candidates to adopt them in their daily work.

Our article served two purposes. Firstly, we wanted to share our professional experiences that we have gathered during participation in numerous recruitment projects (both on the side of the recruited and the recruiter) and provide some remedies for the challenges that we have encountered. Secondly, we wanted to link these situations to the results of research done in the field of industrial and organisational psychology, cognitive psychology, and management studies.

Recognising that management studies, being very practical in nature, are still insufficiently supported by theory (Sułkowski, 2012), we strongly believe that further research in the area of senior-level recruitment is necessary. For further studies, we encourage researchers to analyse in more detail the possible reasons for the reluctance of recruiters to use tools such as AC. Secondly, we believe that it would be beneficial to study short- and long-term effects of an improper recruitment on the company's employees. Finally, taking into consideration that the search for executive positions is usually done by a headhunter it is 
worth to address the topic of cooperation between the company and the headhunting agency as a key factor of the recruitment success.

\section{REFERENCES}

Ansoff, H.I. (1965). Corporate Strategy. New York: McGraw Hill.

Armstrong, M. \& Taylor, S. (2014). Armstrong's Handbook of Human Resource Management Practice. London: Kogan Page Publishers.

Arthur, W. Jr., Day E.A., McNelly T.L. \& Edens P.S. (2003). A meta-analysis of the criterion related validity of Assessment Center dimensions, Personnel Psychology, 56, 125-154.

Arvey, R.D., Gordon, M.E., Massengill, D.P. \& Mussio, S.J. (1975). Differential dropout rates of minority and majority job candidates due to "time lags" between selection procedures, Personnel Psychology, 28(2), 175-180.

Barber, A.E. (1998). Recruiting employees: Individual and organization perspectives. Thousand Oaks, CA: Sage.

Ballantyne, I. \& Povah, N. (2004). Assessment and Development Centres ( $2^{\text {nd }}$ ed.). Hampshire: Gower Publishing, Ltd.

Bell, A.H. (1992). Extraviewing: Innovative Ways to Hire the Best. Homewood, IL: Irwin Professional Pub.

Birkinshaw, J., Bresman, H. \& Hakanson, L. (2000). Managing the post-acquisition integration process: How the human integration and task integration processes interact to foster value creation, Journal of Management Studies, 37(3), 395-425.

Breaugh, J.A. \& Starke, M. (2000). Research on employee recruitment: So many studies, so many remaining questions, Journal of Management, 26(3), 405-434.

Bull, C., Ornati, O. \& Tedeschi, P. (1987). Search, hiring strategies, and labor market intermediaries, Journal of Labor Economics 5(4), S1-S17.

Cappelli, P. \& Keller, J.R. (2014). Talent management: Conceptual approaches and practical challenges, Annual Review of Organizational Psychology and Organizational Behaviour, 1(1), 305-331.

Carroll, M., Marchington, M., Earnshaw, J. \& Taylor, S. (1999). Recruitment in small firms: Processes, methods and problems, Employee relations, 21(3), 236-250.

Clark, T. (1992). Management selection by executive recruitment consultancies: A survey and explanation of selection methods, Journal of Managerial Psychology, 7(6), 3-10.

Coad, A. (2007). Firm Growth: A Survey, Papers on Economics and Evolution 2007-03. Max Planck Institute of Economics, Evolutionary Economics Group. 
Deems, R.S. (1995). Hiring: More Than a Gut Feeling (Edition Unstated edition). Franklin Lakes, N.J: Career Pr Inc.

DePamphilis, D. (2013). Mergers, Acquisitions, and Other Restructuring Activities, Seventh Edition ( $7^{\text {th }}$ ed.). Amsterdam, Boston: Academic Press.

Faulconbridge, J.R., Beaverstock, J.V., Hall, S. \& Hewitson, A. (2009). The 'war for talent': The gatekeeper role of executive search firms in elite labour markets, Geoforum, 40(5), 800-808.

Gërxhani, K. \& Koster, F. (2015). Making the right move. Investigating employers' recruitment strategies. Personnel Review, 44(5), 781-800.

Graves, L.M. \& Karren, R.J. (1996). The employee selection interview: A fresh look at an old problem, Human Resource Management (1986-1998), 35(2), 163-180.

Hayes, S. (1993). Human resources and the bottom line: mistakes are costly!, The Bottom Line, 6(2), 33-35.

Hofstede, G. (2007). Asian management in the $21^{\text {st }}$ century, Asia Pacific Journal of Management, 24(4), 411-420.

Hogarth, R.M. (1980). Judgement and Choice: The Psychology of Decisions. New York: John Wiley and Sons.

HRMI Digest (2007). Coping with the talent shortage: How GE, Rochester and other US firms have approached the recruitment conundrum, Human Resource Management International Digest, 15(3), 6-8.

Jackson, S.E., Brett, J.F., Sessa, V.I., Cooper, D.M., Julin, J.A. \& Peyronnin, K. (1991). Some differences make a difference: Individual dissimilarity and group heterogeneity as correlates of recruitment, promotions, and turnover, Journal of Applied Psychology, 76(5), 675-689.

Jaworowska, A. (2011). Testy $w$ biznesie. Standardy a praktyka. Serock: Pracownia Testów Psychologicznych.

Kahneman, D. (2013). Thinking, Fast and Slow (Reprint edition). New York: Farrar, Straus and Giroux.

Kataoka, H.C., Latham, G.P. \& Whyte, G. (1997). The relative resistance of the situational, patterned behavior, and conventional structured interviews to anchoring effects, Human Performance, 10(1), 47-63.

Kawakami, K., Dovidio, J.F. \& van Kamp, S. (2005). Kicking the habit: Effects of nonstereotypic association training and correction processes on hiring decisions, Journal of Experimental Social Psychology, 41(1), 68-75.

Kerr, N.L. \& Tindale, R.S. (2004). Group performance and decision making, Annual Review of Psychology, 55, 623-655.

Kostera, M. (2000). Zarzadzanie personelem. Warszawa: PWE.

Lachowski, S. (2013). Od wartości do działania: przywództwo w czasach przełomowych. Warszawa: Wydawnictwo Studio Emka. 
Ma, R. \& Allen, D.G. (2009). Recruiting across cultures: A value-based model of recruitment, Human Resource Management Review, 19(4), 334-346.

Mazur, B. (2012). Zarządzanie różnorodnością kulturowa, Wspótczesne Zarządzanie, 3, 144-153.

McDaniel, M.A., Whetzel, D.L., Schmidt, F.L. \& Maurer, S.D. (1994). The validity of employment interviews: A comprehensive review and meta-analysis, Journal of Applied Psychology, 79, 599-661.

Mileham, P. (2000). The 'science' of headhunting, Drug discovery today, 5(4), 161-163.

Molenda, M. (2010). Pozyskiwanie pracowników - analiza błędów kadry rekrutującej, Edukacja Ekonomistów i Menedżerów, 2(16), 165-175.

Moscovici, S. \& Zavalloni, M. (1969). The group as a polarizer of attitudes, Journal of Personality and Social Psychology, 12(2), 125-135.

Newell, S. (2005). Recruitment and Selection. In: S. Bach (ed.), Managing Human Resources: Personnel Management in Transition (pp. 115-147). Oxford: Blackwell Publishing.

Olszak, E. (2014). Nowoczesny dobór personelu - kierunki rozwoju metod i narzędzi w rekrutacji i selekcji. Prace Naukowe Uniwersytetu Ekonomicznego we Wrocławiu, 349: Sukces w zarzadzaniu kadrami. Różnorodność w zarzadzaniu kapitałem ludzkim - podejścia, metody, narzędzia. Problemy zarzqdczo-ekonomiczne, 283-294.

von Raffler-Engel W. (1983). The Perception of Nonverbal in the Career Interview. Amsterdam-Philadelphia: John Benjamins Publishing.

Rousseau, V., Aubé, C. \& Savoie, A. (2006). Teamwork behaviors a review and an integration of frameworks, Small Group Research, 37(5), 540-570.

Roselius, W. \& Kleiner, B.H. (2000). How to hire employees effectively, Management Research News, 23(12), 17-23.

Russo, G., Gorter, C., Nijkamp, P. \& Rietveld, P. (1997). Employers' recruitment behaviour: an empirical analysis of the role of personnel management attitudes, Labour, 11(3), 599-623.

Russo, G., Rietveld, P., Nijkamp, P. \& Gorter, C. (1995). Issues in recruitment strategies: an economic perspective, International Journal of Career Management, 7(3), 3-13.

Russo, G., Rietveld, P., Nijkamp, P. \& Gorter, C. (2000). Search channel use and firms' recruitment behavior, De Economist, 148(3), 373-393.

Rynes, S.L. (1991). Recruitment, job choice, and post-hire consequences: A call for new research directions. In: M.D. Dunnette, L.M. Hough (eds.), Handbook of industrial and organizational psychology (vol. 2, pp. 399-444). Palo Alto, CA: Consulting Psychologists Press. 
Rynes, S.L., Bretz, R.D. \& Gerhart, B. (1991). The importance of recruitment in job choice: A different way of looking, Personnel Psychology, 44, 487-521.

Smircich, L. (1983). Concepts of culture and organizational analysis, Administrative Science Quarterly, 28, 339-358.

Spence, L.J. (2016). The Obfuscation of Gender and Feminism in CSR Research and the Academic Community: An essay. In: K. Grosser, L. McCarthy, M. Kilgour (eds.), Gender Equality and Responsible Business: Expanding CSR Horizons. Greenleaf Publishing: Sheffield, UK.

Sułkowski, Ł. (2012). Epistemologia i metodologia zarzadzania. Warszawa: PWE.

Szkop, K. (2012). Trafność metod doboru personelu wykorzystywanych w przedsiębiorstwach. In: A. Grzegorczyk (eds.), Procesy decyzyjne w warunkach niepewności (pp. 110-134). Warszawa: Wyższa Szkoła Promocji.

Taylor, M.S. \& Collins, C.J. (2000). Organizational recruitment: enhancing the intersection of research and practice. In: C.L. Cooper, E.A. Locke (eds.), Industrial and organizational psychology: Linking theory and practice (pp. 304-334). Oxford, UK: Blackwell.

Tixier, M. (1996). Employers' recruitment tools across Europe, Employee Relations, 18(6), 69-80.

Uggerslev, K.L., Fassina, N.E. \& Kraichy, D. (2012). Recruiting through the stages: A meta-analytic test of predictors of applicant attraction at different stages of the recruiting process, Personnel Psychology, 65(3), 597-660.

Van Clieaf, M.S. (1992). Strategy and structure follow people: Improving organizational performance through effective executive search, Human Resource Planning, 15(1), 33-46.

Vieira Campos Proença, M.T. \& Valente Dias de Oliveira, E.T. (2009). From normative to tacit knowledge: CVs analysis in personnel selection, Employee Relations, 31(4), 427-447.

Raffler-Engel, W.V. (1983). The Perception of Nonverbal Behaviour in the Career Interview. Amsterdam: John Benjamins Publishing Company.

Wachowiak, P. (2006). Polityka personalna $w$ przedsiębiorstwach działajacych $w$ Polsce. Dobór pracowników, raport z badań własnych. Warszawa: Szkoła Główna Handlowa.

Wachowiak, P. (2009). Kluczowe czynniki sukcesu w zarządzaniu zasobami ludzkimi, Prace i Materiaty Wydziatu Zarzadzania Uniwersytetu Gdańskiego. Zeszyty Naukowe Uniwersytetu Gdańskiego. Zagadnienia Ekonomiki Przemystu, 2/3, 1087-1095.

Witkowski, T. (ed.) (2007). Dobór personelu: koncepcje-narzędzia-konteksty. Taszów: Moderator. 


\section{REKRUTACJE CZKONKÓW ZARZĄDÓW - NAJCZĘŚCIEJ WYSTĘPUJĄCE BKĘDY ORAZ SPOSOBY ICH ZAPOBIEGANIA}

\section{Abstrakt}

Tło badań. Znalezienie odpowiedniego kandydata na stanowisko wyższego szczebla jest zadaniem złożonym, a jego skutki maja zazwyczaj istotny wpływ na funkcjonowanie firmy zarówno w perspektywie krótkoterminowej, jak i długofalowo. Zważywszy na tak poważne konsekwencje, można byłoby przypuszczać, że rekrutacja na stanowiska zarządzające jest procesem przeprowadzanym w sposób ustrukturyzowany i rzetelny. Niestety wyniki badań z dziedziny selekcji kandydatów wskazuja, że bardzo często tak nie jest.

Cele badań. Celem artykułu jest opisanie najczęściej spotykanych błędów poznawczych i organizacyjnych typowych dla procesu rekrutacji kandydatów na wysokie stanowiska. Dodatkowo artykuł zawiera zbiór rekomendacji dotyczących sposobów eliminacji najczęstszych problemów.

Metodologia. Najczęściej występujące błędy w rekrutacji na najwyższe stanowiska zostały zidentyfikowane na podstawie przeglądu literatury z dziedziny zarządzania. Wnioski wzbogacono przykładami i obserwacjami z praktyki własnej autorów badania oraz zinterpretowano w odniesieniu do badań z zakresu psychologii poznawczej i społecznej.

Kluczowe wnioski. Do najczęstszych błędów organizacyjnych można zaliczyć: brak planu rekrutacji, mało precyzyjny opis kandydata na stanowisko, niestosowanie narzędzi rekrutacyjnych innych niż rozmowa kwalifikacyjna, brak uwzględnienia dopasowania kandydata do kultury firmy i rynku, niedostateczna komunikacje $\mathrm{z}$ kandydatami oraz błędy poznawcze w procesie decyzyjnym. W artykule przedstawiono rekomendacje dotyczace zaradzenia tym problemom.

Słowa kluczowe: proces rekrutacyjny, wybór kandydatów, kadra zarządzająca, błędy poznawcze. 